\title{
Motivation to Transfer Training and Individual Performance: the Influence of Transformative Learning and Supervisor Support
}

\author{
Emiliana Sri Pudjiarti, Honorata Ratnawati Dwi Putranti, Nurchayati \\ Faculty of Economics and Business, Universitas 17 Agustus 1945, Semarang, Indonesia
}

\begin{tabular}{l} 
Info Article \\
History Article: \\
Submitted 26 June 2019 \\
Revised 15 November 2019 \\
Accepted 18 November 2019 \\
\hline Keywords: \\
Transformative Learning; \\
Supervisor Support; Motivation \\
to Transfer Training; Individual \\
Performance.
\end{tabular}

Performance.

\begin{abstract}
The aim of research discusses the mediating role of motivation to training transfer as mediation in the relationship between supervisor support and transformative learning on lecturer performance. Survey methods and purposive non random sampling techniques were used with the help of a questionnaire based on a 7-point Likert scale. The number of fit samples was 199 to test the hypothesis. Amos and structural models are used to test the statistical significance of the path coefficients. The findings of the study explain that supervisor support and transformative learning can encourage lecturers to make intense efforts in utilizing the skills and knowledge learned during the training process. The study also highlighted the motivation of training transfer as the key to successfully improving lecturer performance. Training plays an important role in the HRM strategy in an effort to renew the HRM competencies needed by the organization today. Therefore, motivation for training transfer is an important problem faced by professionals in developing HRM. This means that positive transfer training motivation requires that trainees can effectively apply what has been learned to the job, which leads to meaningful changes in performance.
\end{abstract}

\section{Motivasi untuk Mentransfer Pelatihan dan Kinerja Individu: Pengaruh Pembelajaran Transformatif dan Dukungan Supervisor}

\begin{abstract}
Abstrak
Tujuan penelitian ini membahas peran mediasi motivasi transfer pelatihan sebagai mediasi dukungan supervisor dan pembelajaran transformatif terhadap kinerja dosen. Metode survei dan teknik purposive non random sampling digunakan dengan bantuan kuesioner yang mendasarkan skala Likert 7 poin. Jumlah sampel fit sebanyak 199 untuk menguji hipotesis. Amos dan model struktural digunakan untuk menguji signifikansi statistik koefisien jalur. Temuan hasil penelitian menjelaskan bahwa dukungan supervisor dan pembelajaran transformatif dapat mendorong dosen untuk melakukan upaya yang intens di dalam memanfaatkan keterampilan dan pengetahuan yang dipelajari saat proses pelatihan. Penelitian juga menyoroti motivasi transfer pelatihan sebagai kunci sukses meningkatkan kinerja dosen. Dengan demikian pelatihan memainkan peran penting dalam strategi HRM dalam upaya memperbarui kompetensi HRM yang dibutuhkan organisasi saat ini. Motivasi transfer pelatihan merupakan masalah penting yang dihadapi oleh para profesional dalam pengembangan HRM. Artinya motivasi transfer pelatihan secara positif mensyaratkan bahwa peserta pelatihan secara efektif dapat menerapkan apa yang telah dipelajari pada pekerjaan, yang mengarah pada perubahan yang berarti dalam kinerja.
\end{abstract}

JEL Classification: M1, M13

How to Cite: Pudjiarti, E. S., Putranti, H. R. D., \& Nurchayati. (2019). Motivation to Transfer Training and Individual Performance: the Influence of Transformative Learning and Supervisor Support. Jurnal Dinamika Manajemen, 10(2), 148-161. 
Emiliana Sri Pudjiarti et al./ Motivation to Transfer Training and Individual Performance: the Influence....

\section{INTRODUCTION}

The latest developments in higher education management where both institutions and employees are encouraged to increase their capacity and competitiveness have substantially changed the paradigm of teaching management in tertiary institutions which had so far focused on textual teaching to be research intensive. Moreover, higher education has a strategic role in the development of HRM both formally operational technical as well as theoretical mastery and empirical practice. To deal with this, universities are expected to adopt special processes in order to encourage improvements in the teaching and learning process both explicitly and implicitly by building awareness of the importance of learning as a basis for encouraging the development of higher education. The flexibility of tertiary institutions in developing strategic resources requires a long-term commitment in a dynamic environment (Suparjo \& Sunarsih, 2018). In this case, universities must always be oriented towards transformational learning, where individuals have views on everything that works in a complex manner, and try to adjust their thinking to accommodate a more accurate and expansive understanding. Transformation can be in the form of realizing discipline and self-understanding in relation to the world, including in this case the task of academic staff in journal writing, learning contracts, case studies, and using literature, all of which are to stimulate critical awareness (Mezirow, 2012).

Transformative learning theory emphasizes the potential to improve work outcomes, because transformative learning is a learning theory for adults that requires a certain fundamental change (Christie et al., 2015). Fundamental changes associated with the existence of a certain stagnation that originates in the cognitive and emotional dimensions, so that the difficulties faced by employees to develop their potential can be overcome. According to Dirkx (2012) the transformation of lear- ning not only knows more, but understands new ways. The new ways are more inclusive discriminatory, open, reflective, and able to change emotionally. This condition illustrates that when top management recognizes the importance of knowledge management as the center of strategic planning, employees feel they have a role and feel more aligned and connected with organizational goals (Hasani \& Sheikhesmaeili, 2016). It is important to pay attention to transformative learning for employees, because it can improve operational excellence and transfer training as a valuable strategy to facilitate learning at both the micro and macro levels and to gain benefits in all aspects of learning (Heddy et al., 2017).

In connection with fostering performance, the facilitation system to monitor performance can help employees understand the extent to which employee development can be realized as a result of learning through training, which in turn will reflect the commitment of employees to transfer knowledge to their work assignments. Knowledge transfer helps ensure that HRM as human capital becomes the most valuable resource, because through training, employers can motivate performance and assist in the transition of employees. Sufficient training shows that employers care about the personal development of employees which in turn reflects the development of the organization (Tomé \& Goyal, 2015; Hanaysha \& Tahir, 2016; Choi \& Jeong, 2017). Therefore, supervisor support in giving individual instructions and guidance to employees in the context of daily work becomes very important. This activity is referred to as informal training, which is defined as an unstructured development process in which managers provide feedback and guidance one by one to employees to improve employee performance (Liu \& Batt, 2010).

In the context of gap research, there are several studies that cannot establish a significant relationship between supervisor support and employee performance (Van der Locht 
et al., 2013). The negative effects of manager support on the transfer of training in the workplace that cannot boost performance. In these studies, managers' efforts to help employees appear to hamper employee performance at work (Hossain \& Aktar, 2012). This finding explains that the relationship between supervisory support and employee performance is still unclear (Blume et al., 2010; Bhatti \& Chee, 2012). Several other studies Dumas et al. (2010) found that supervisor support has a positive impact on individual productivity which in turn increases organizational performance (Dumas et al., 2010). This theoretical gap is the basis for the need for this research.

Supervisor support refers to the proactive behavior of supervisors in helping employees to demonstrate the skills, knowledge, and attitudes obtained from training programs (Huang \& Hsieh, 2015). Supervisors play an important role in training, because without the support of supervisors, the transfer of training will not succeed (Bhatti \& Chee, 2012). This happens because employees tend to be less focused on when not monitored or monitored. Supervisor support can be emotional, instrumental support (Wei Tian et al., 2016; Tucker et al., 2018). This support can be given before and after the training program. This can also be in the form of feedback which is a form of supervisor support. Relative feedback is seen as part of supervisor support where supervisors identify areas in which employees need to be improved, are encouraged to join training programs, and help apply skills learned after completing work. Egan et al. (2004) in their empirical research, prove that the transfer of learning has a significant influence on the motivation of trainees to transfer knowledge. The study specifically found that participants who were more serious about adding value from the training were more motivated to transfer training to work than those who did not have a specific purpose for attending the training.

Conceptually based on the findings of Egan et al. (2004), this article proposes motivation to transfer training to be a mediating variable in the relationship between supervisor support and employee performance. The issue raised specifically is how to support supervisors and transformative learning in an effort to improve the performance of lecturers by mediating motivation to training transfer. This study was conducted at a private tertiary institution in Central Java with the unit of observation being lecturer HRM, considering that lecturer HRM is a dominant factor in the success of a tertiary institution. Therefore, Higher Education requires qualified HRM to carry out its role in serving the needs of both situational and predictive practical knowledge. As an agent of innovation, Higher Education has a role in developing science, disseminating, socializing, applying knowledge and producing learning societies that are expressed with a passion for searching for information, using, and communicating knowledge. As an agent of change, Higher Education has consequences for the application of innovative products to become a catalyst for social transformation.

The purpose of this study is to analyze the effect of transformative learning on motivation to transfer training, supervisor support on motivation to transfer training, and motivation to transfer training on individual performance. The main theory used in this study is transformative learning developed by Jack Mezirow, Professor of Adult Education at Teachers College, Columbia University, New York. Transformative learning as metacognitive reasoning where learning is associated with assessing reason and frame of reference and experience-feelings, values, concepts, associations, responses in adults (Mezirow, 2000). In this study, the concept of transformative learning is tested on college lecturers, where this learning is useful in increasing self-awareness of lecturers to share knowledge to improve institutional performance. Previous studies of the influence of motivation on employee performance largely focused on the company. The novelty in this study is to combine transformative learning and supervisor support that is mediated by motivation to improve individual performance. 
Emiliana Sri Pudjiarti et al./ Motivation to Transfer Training and Individual Performance: the Influence....

\section{Hypothesis Development}

Transformative learning is defined as an increase in individual awareness oriented to critical thinking through transformation of perspectives and specific capacities based on cognitive and communicative dimensions (Novak \& Gowin, 2004). When adults face something new, they are likely to reflect on and talk with others about the accuracy and adequacy of assumptions, and to gain new insights to change attitudes, behavior, and beliefs (Hoggan, 2016). Learning to re-evaluate and retell previous learning experiences can make adults understand their experiences and find a new sense of identity. Here, transformative learning generally refers to the concept of individual-oriented learning from the perspective of critical thinking by relying on cognitive, social, rational, emotional, and communicative dimensions.

Transformation in learning occurs in the perspective of values, terms of reference, and mindset (Mezirow, 2000). This happens where a person actively faces a limiting or problematic structure in understanding, and struggles simultaneously to build a new structure (Mezirow, 2012). The result is not only knowing more ways, but understanding new ways (Dirkx, 2012). The new structure is more inclusive, discriminatory, open, reflective, and able to change emotionally (Mezirow, 2012).

Transformational learning is considered as an important antecedent of employee willingness to learn and share knowledge (Bates et al., 2012). The willingness of participants to use and share knowledge and skills gained from training can be defined as their motivation for transferring training. Motivation to transfer training involves encouraging or inspiring individuals to apply knowledge gained from formal or informal learning to a particular work context. Based on the description, the first hypothesis proposed is:

H1: Transformative learning has a positive effect on motivation to transfer training.
Supervisor support reflects the supervisor's role in optimizing the use of employee knowledge, skills and attitudes acquired during training (Nijman et al., 2006). This variable is one of the variables in social support that exists in a well-known transfer system learning model (Holton III et al., 2000). This support encourages trainees to use newly learned skills, identify situations to use these new skills, and provide guidance on the appropriate application of skills, providing feedback, positive reinforcement on new applications, all of which can facilitate training transfer (Ghosh et al., 2015).

Support from supervisors on training transfers consists of various actions that influence trainees' perceptions about the importance of training and efforts to obtain training content and apply it to work (Towler et al., 2014). Supervisor support was shown by behaviors such as helping set goals, providing assistance when trying new behaviors and feedback on task performance (Ghosh et al., 2015).

Supervisor support refers to the support felt and received by trainees from their direct supervisors before and after training (Reinhold et al., 2018). Some literature reveals that supervisory support influences the motivation of subordinate training and the level of efficacy of trainees because of its positive impact on the performance of trainees (Massenberg et al., 2015).

The findings of Ghosh et al. (2015) concluded that supervisors' support indirectly impacts the transfer of training with the mediating role of the characteristics of trainees. Here, human resource managers can ensure that supervisors play the catalyst role in utilizing the characteristics of trainees by increasing motivation to learn and motivation to transfer trainees. Supervisors can assist trainees in increasing their transfer rates by familiarizing them with the all program. Based on the description, the proposed second hypothesis is:

H2: Supervisor support has a positive effect on motivation to training transfers. 
Training is an organized process to improve employees' knowledge, competencies and skills in achieving goals for specific work tasks (Alshery et al., 2015; Kirwan, 2016; Huang et al., 2017). There are three theories about training transfer, namely motivation theory, training transfer design theory, and theories that support transfer climate (Holton III, 1996). The motivation theory is categorized into three theories, namely equity theory, expectancy theory, and work regulation theory. The transfer level of training is positively associated with the choice of individuals to apply their knowledge, skills and attitudes in the workplace. Thus, training transfer is defined as the extent to which participants can apply the knowledge, skills and attitudes acquired during training in the context of their own work (Blume et al., 2010). Transfers can occur when an employee's learned behavior from training is generalized to his own job and maintained for a certain period of time (Blume et al., 2010).

Work motivation theory shows that motivation precedes action (Muduli \& Raval, 2018), but expectation theory reveals that motivation to transfer refers to the desires of individuals who utilize the knowledge and skills gained from training programs in their workplaces (Iqbal \& Dastgeer, 2017). Create inspiration, individuals need to reassign knowledge and skills from training to specific work contexts (Noe \& Schmitt, 1986; Dong et al., 2017; Banerjee et al., 2017; Medina, 2017).

Thus, motivation to transfer training is defined as the desire of trainees to use the knowledge and skills learned during the training process in the workplace. Intrinsic rewards such as the feeling of success, achievement, higher performance can cause employee satisfaction so that they are motivated to transfer knowledge and skills obtained from training programs to get career advancement opportunities (Martin-Perez \& Martin-Cruz, 2015). Motivation to transfer training involves encouragement or inspiration from personal experience gained from work and is useful for certain jobs. Based on the description, the proposed third hypothesis is:
H3: Motivation to transfer training has a positive effect on individual performance

\section{METHOD}

This study uses quantitative methods to analyze the effect of transformative learning on improving performance in a private tertiary institution. This study uses quantitative methods to analyze the effect of transformative learning on improving performance in a private tertiary institution. The data in this study were obtained from secondary data on the directory of the number of private lecturers from the Dikti Service Institution in the Central Java region. Data collection was carried out by surveying through the distribution of questionnaires. In detail, this study uses primary data that is collected through questionnaires by utilizing the google drive which is collected through WhatsApps to lecturers in the environment of the Institute of Higher Education Service in Central Java as respondents. Samples were taken as many as 225 lecturers who were determined by a purposive random sampling technique. However, because of many respondents did not give answers, the data was declared fit only 199 questions.

Variable measurements of transformative learning were by using indicators adopted from McGonigal (2005) which propose five indicators of transformative learning, namely: activating the event, identifying initial, critical reflection, dialogue and discussion, and applying a new perspective. The measument of supervisor support variable was adopted from Chen et al. (2015) consisting of 4 indicators that are performance expectations, identification of opportunities, setting realistic goals, and collaboration between individuals. The motivation to training transfer variable was measured by using the indicators from Noe and Schmitt (1986) consisting of 4 indicators: confidence in work-based training output, adding experience, apply knowledge, and applying expertise. The individual performance variable was measured by using 
Emiliana Sri Pudjiarti et al./ Motivation to Transfer Training and Individual Performance: the Influence....

indicators adopted from Hersey et al. (1996) consisting of 5 indicators: writing textbooks, making classroom atmosphere conducive, research, scientific publications, and community service. The scale of supervisor support is taken from Chen et al. (2015) consisting of 4 indicators which are performance expectations, identification of opportunities, setting realistic goals, and collaboration between individuals. All items were measured by using a Likert scale of 1 (strongly disagree) to 7 (strongly agree).

The data analysis technique is used in the Structural equation modeling (SEM) as a tool to test the relationship between complex variab- les and to obtain a comprehensive overview of the entire model. The used software is AMOS version 24.00 .

\section{RESULT AND DISCUSSION}

Dimensional Analysis, Reliability, and Validity

The results of the data test analysis in Table 1 explain about Exploratory Factor Analysis (EFA) as one method of factor analysis to identify the relationship between manifest variables in building constructs.

The results of the factor analysis with the Kaiser Meyer Olkin test (KMO) (column 5) showed a value above 0.7 . This explained that the data

Table 1. Test for Data Conformity

\begin{tabular}{|c|c|c|c|c|}
\hline Variable \& Indicator & Loading & $\begin{array}{l}\text { Construct } \\
\text { Reliability }\end{array}$ & $\begin{array}{l}\text { Variance } \\
\text { Extracted }\end{array}$ & $\begin{array}{l}\text { Indicator } \\
\text { Validity }\end{array}$ \\
\hline (1) & $(2)$ & (3) & (4) & $(5)$ \\
\hline Transformative learning & & .843 & .518 & \\
\hline Identifying initial assumptions & .724 & & & .808 \\
\hline Applying a new perspective & .726 & & & .757 \\
\hline Dialogue and discussion & .734 & & & .753 \\
\hline Critical reflection & .705 & & & .782 \\
\hline Activating event & .767 & & & .813 \\
\hline Supervisor Support & & .814 & .522 & \\
\hline Performance expectations & .724 & & & .798 \\
\hline Identification of opportunities & .726 & & & .803 \\
\hline Setting realistic goals & .734 & & & .810 \\
\hline Collaboration between individuals & .705 & & & .792 \\
\hline Motivation to training transfer & & .801 & .502 & \\
\hline Confidence in work-based training output & .683 & & & .781 \\
\hline Adding experience & .708 & & & .798 \\
\hline Applying knowledge & .720 & & & .801 \\
\hline Applying expertise & .722 & & & .800 \\
\hline Individual performance & & .852 & .536 & \\
\hline Writing textbooks & .717 & & & .798 \\
\hline Making the classroom atmosphere conducive & .776 & & & .803 \\
\hline Research & .734 & & & .810 \\
\hline Scientific publications & .706 & & & .792 \\
\hline Community service & .726 & & & \\
\hline
\end{tabular}


was declared valid. Column 1 analyzes whether an indicator enters to a particular indicator in EFA. The measure is when the loading factor value is more than 0.6 ; convergent validity is regarded to have a significant loading factor. Next, column 3 explains the reliability of all latent variables produced with the standard of reliability coefficient higher than 0.7 , a value that is considered adequate (Hair et al., 1998). The variance extracted value in column 4 shows higher values than 0.5 . The conclusion obtained from the results of the EFA analysis is that the data can be declared fit or appropriate, so that the structural analysis of the next model equation can be further continued.

\section{Respondent Demography}

The data identification from 199 respondents explained several things that are related to gender, age, recent education, teaching experience, and academic positions, such as shown in Table 2.

Table 2. Demographic Profile of Respondents

\begin{tabular}{lll}
\hline Information & Total & \% \\
\hline Gender : & & \\
a) Male & 108 & $54.27 \%$ \\
b) Female & 91 & $45.73 \%$ \\
\hline Age : & & \\
a) 31-40 years & 23 & $11.56 \%$ \\
b) 41-55 years & 78 & $39.20 \%$ \\
c) 56-60 years & 66 & $33.17 \%$ \\
d) 61-65 years & 27 & $13.57 \%$ \\
e) $>65$ years & 5 & $2.51 \%$ \\
\hline Education : & & \\
a) S2 & 172 & $86.43 \%$ \\
b) S3 & 27 & $13.57 \%$ \\
\hline Teaching Experience & & \\
a) <5 years & 19 & $9.55 \%$ \\
b) 6-10 years & 27 & $13.57 \%$ \\
c) 10-15 years & 36 & $18.09 \%$ \\
d) 16-20 years & 43 & $21.61 \%$ \\
e) 21-25 years & 31 & $15.58 \%$ \\
f) 26-30 years & 34 & $17.09 \%$ \\
g) > 30 years & 9 & $4.52 \%$ \\
\hline Academic Position: & & \\
a) Expert Assistant & 18 & $9.05 \%$ \\
b) Lecturer & 87 & $43.72 \%$ \\
c) Senior Lecturer & 79 & $39.70 \%$ \\
d) Professor & 15 & $7.54 \%$ \\
\hline
\end{tabular}

Most of the respondents were male (54.27\%). This condition illustrates that the dominance of the work of lecturers is still dominated by men, and has matured in age so that they are able to make decisions with careful consideration. The majority of respondents are lecturers aged above 55 years and quite a lot reaching $49.25 \%$. Lecturers of the private universities in Central Java are classified on adults and are not easily influenced in the selection of jobs and development of knowledge, but in the future regeneration must occur immediately.

Respondents involved in the study have the potential to transfer knowledge and improve performance. Furthermore, the lecturers must have academic qualification which is obtained through high education postgraduate programs in accordance with the expertise of their fields. Most of the respondents were educated with a master degree (86.43\%) and as many as $13.57 \%$ had doctorate education. The data shows that the lecturers have fulfilled the constancy of Law Number 14 of 2005, which states that a lecturer must have an academic qualification of at least a master.

Most of the academic positions are lecturers $(43.72 \%)$, senior lecturers $(39.70 \%)$ and expert assistants (9.05\%), while professors are only $7.54 \%$. Related to work experience, most of them have been over 15 years, so they have understood the duties and responsibilities as lecturers. Lecturer certificates as formal proof of self capacity refer to a series of competency tests in the form of portfolio assessments on the basis of academic, experience and professional assessment.

\section{Goodness of Fit Model}

SEM testing could be done with two approaches, namely individual and simultaneous tests. The individual test uses the $t$ test which is confirmed with a standard error level of 0.05 . The covariance matrix is used as a basis for measuring the level of fitness model in structural quation modeling (Figure 1). 
Emiliana Sri Pudjiarti et al./ Motivation to Transfer Training and Individual Performance: the Influence....

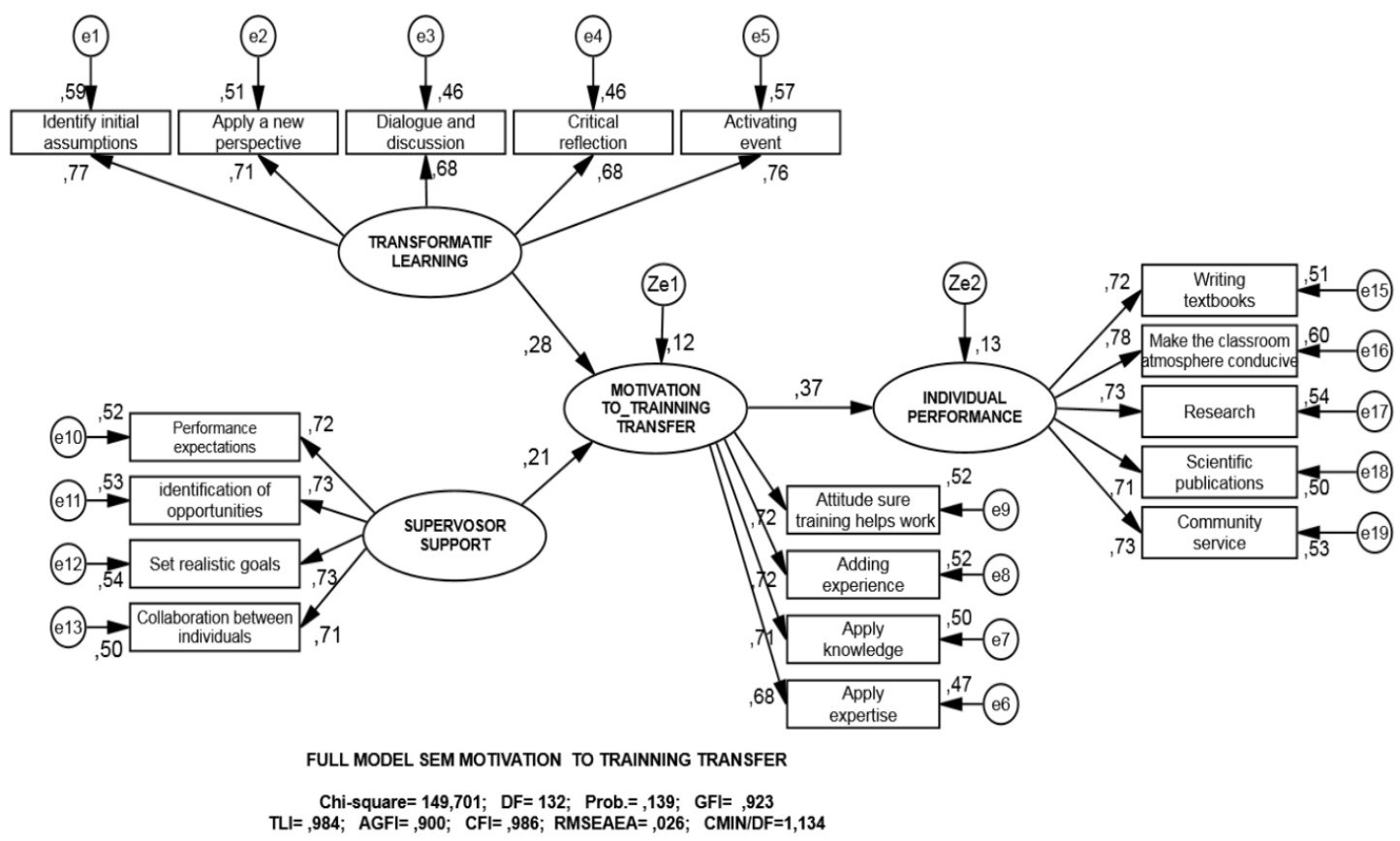

Figure 1. Full Model SEM Motivation

Based on Table 3, it can be concluded that the resulted lane model is declared fit because it is on the range of required cut-off values. Only the Normed Fit Index (NFI) which has a marginal condition. It is no problem because it is still in the range close to number one. In the test of SEM assumptions, it was also found that the data had been declared normal in both the multivariate and univariate dimensions, free from outliers both multivariate and univariate, as well as being free from multicollinearity and singularity. Thus,

Table 3. Goodness of Fit Model

\begin{tabular}{lrrc}
\hline Criteria of Fit & Cut-off Value & Result & Note \\
\hline Absolute Fit Test & & & \\
Chi-Square & $<139.9$ & 149.7 & Fit \\
P- Value & $>.05$ & .139 & Fit \\
Goodness of Fit Indeks (GFI) & $>.90$ & .923 & Fit \\
Root Mean Square Error of Approximation (RMSEA) & $<.08$ & .026 & Fit \\
Chi-Square /DF (Cmin/DF) & $<2.00$ & 1.134 & Fit \\
\hline Incremental Fit Measures & & & \\
Ajusted GFI (AGFI) & $>.90$ & .900 & Fit \\
Normed Fit Index (NFI) & $>.90$ & .888 & Marginal \\
Comparative Fit Index (CFI) & $>.90$ & .986 & Fit \\
Incremental Fit Index (IFI) & $>.90$ & .981 & Fit \\
Relative Fit Index (RFI) & $>.90$ & .919 & Fit \\
Tucker-Lewis Index & $>.90$ & .984 & Fit \\
\hline Parsimonius Fit Measures & & & \\
Parsimonious Normed Fit Index (PNFI) & $>.90$ & .923 & Fit \\
Parsimonious CFI (PCFI) & $>.90$ & .936 & Fit \\
\hline
\end{tabular}


the model can be declared fit, so that it can be used for the next analysis of hypothesis testing.

\section{Hypothesis Testing}

The testing of three hypotheses are shown in Table 4.
Another important highlight from these results is the process of transformation form the change in one's frame of reference. The frame of reference consists of thinking habits and views (Mezirow, 2012). These habits depict broad, abstract, forward-oriented ways of thinking, feeling, and acting, all of which are influenced by assumptions

Table 4. Structural model path coefficients

\begin{tabular}{lllcccc}
\hline Path & & & $\begin{array}{c}\text { Standardized } \\
\text { Path Estimate }\end{array}$ & S.E. & C.R & P \\
\hline Transformative learning & $\rightarrow$ & Motivation to training transfer & .278 & .084 & 3.125 & .002 \\
$\begin{array}{l}\text { Supervisor support } \\
\begin{array}{l}\text { Motivation to training } \\
\text { transfer }\end{array}\end{array}$ & $\rightarrow$ & Motivation to training transfer & .212 & .092 & 2.381 & .170 \\
\hline
\end{tabular}

The first hypothesis testing regarding the effect of transformative learning on motivation to training transfer shows empirically significant results with $\mathrm{CR}=3.125>\mathrm{t}$ table $=1.65$, and $\mathrm{p}$ value $=0.002<0.05$. This study explains that the higher the transformative learning, the higher the motivation to transfer training. This study explains that increasing transformative learning is more likely to increase the motivation of lecturers to transfer training. This is because transformative learning that focuses on capacity building through self-reflection and critical thinking is not only empirically proven to be able to improve the cognitive and rational dimensions of private university lecturers, but also the social, emotional and communication dimensions. Increasing social awareness and communication in turn increases the motivation to share knowledge gained from training to fellow lecturers.

This result is consistent with the results of Egan et al. (2004) revealing that the transfer of learning has a significant influence on the motivation of trainees to transfer knowledge. Participants who are more serious in building knowledge will be more motivated to transfer training than those who do not have specific objectives in training. This is confirmed by Dirkx (2012) by categorizing the development of transformative learning into four components, in form of transformations in awareness raising, critical reflection, development process, and individuation. which are a set of cultures, politics, social education, and economics. Habits of thinking are expressed through certain perspectives, such as beliefs, values, attitudes, and feelings that form certain interpretations. Transformative learning is based on a constructive paradigm that actualizes individuals to build knowledge through experience. Transformative learning also has implications for the process of acquiring socially constructed knowledge by a group of individuals. The point of view can change continuously when learning and reflect on the meaning of learning or the process of being able to solve problems and identify needs. However, this result is somewhat different from the findings of Niro (2014) stating that with the rapid technological pace in a fast-paced knowledge economy, transformative learning in adult education requires a proactive institutional context that stimulates them to learn deeply. Adults are active participants and are involved in the learning process, creating or building what they learn when they learn rather than taking content or subject matter passively.

The second hypothesis testing regarding the influence of supervisor support on motivation to training transfer shows significant results with $\mathrm{CR}=2.381>\mathrm{t}$ table $=1.65$, and $\mathrm{p}$-value $=0.017$ $<0.05$. This study concludes that the higher the supervisor support, the higher the motivation to training transfers. This means that increasing support from supervisors is more likely to increase 
the motivation of lecturers to share knowledge. In detail, the supervisor can identify several important aspects in setting targets during training. These aspects include performance expectations, identification of opportunities, setting realistic goals, and collaboration between individuals. Identification of targets and opportunities for trainees as well as supervisor's encouragement to lecturers to increase collaboration are more likely to be able to increase motivation for lecturers to transfer training. This is in accordance with the psychological basis that teamwork can increase togetherness and achieve shared targets. The division of work on collaborative-based tasks can increase the efforts of lecturers to find out and share knowledge with fellow teams to complete tasks and achieve shared goals.

Many empirical studies report that supervisor support has a beneficial effect on the transfer of training in progress (Heilmann et al., 2013; Govaerts \& Dochy, 2014). This finding explains that training cannot instantly produce results unless management continues to support it and is involved in it. The superiors' support is not only formal but also informal. Superiors' support is not only limited to the content of training programs, but is extended to the work environment, especially supervisory support at each stage of the training program.

The findings that support from supervisors depend on supporting facilities available at the workplace (Arefin \& Islam, 2019). If support facilities are available and supervisors behave positively, participants will be motivated to apply their training knowledge to work. The opportunity to do is related to a favorable work environment. If the work environment does not support trainees, they will not be interested in applying their knowledge in practice. High performance does not only encourage learning but also applies to learn outcomes into actions that can improve performance (Battor \& Battor, 2013). The transfer of training is done when the trainee leaves the training venue and applies what he has obtained directly or indirectly through support from superiors or colleagues (Ghosh et al., 2015). In learning how to improve training effectiveness, and transferring it, support from supervisors can help employees apply what they have learned from training (Blume et al., 2010). In general, supervisor support for training transfer is described as the extent to which supervisors strengthen and support training results in the workplace (Holton III et al., 2000; Priyotomo et al., 2019).

The third hypothesis testing showed significant results of motivation to training transfer on individual performance with $\mathrm{CR}=3.979>1.65$, and sig.t $=0.00<0.05$. This study explains that the higher the motivation to training transfer, the higher the performance of individuals proves to be significant. This study explains that the higher the motivation for training transfer, the higher the performance of individuals proving to be significant. This means that increased motivation for training transfer is more likely to improve individual performance. Motivation for the transfer of training is carried out by several measures such as lecturers' confidence in the results of work-based training, increased experience during training, and the possible application of knowledge and expertise can help lecturers complete their teaching and research tasks more effectively. This proves that motivation for transferring training can increase the capacity of lecturers in private universities and in turn improve individual performance in the fields of teaching, scientific publications and community service.

This finding is in line with Bjerregaard et al. (2016) stating that training is considered effective if investments made can improve skills/ knowledge and can be applied/transferred in the workplace. Investment in training brings unique benefits to the organization because training increases organizational performance. This can be achieved through the expansion of motivation, skills, and learning (Bulut \& Culha, 2010). The transfer of training is comprehensively adopted as one of the important elements that build employee performance and obtain a higher return on investment (Namian et al., 2016). Moreover, Arefin and Islam (2019) found that training programs at banks in Bangladesh are able to increase the level of trust of trainees, and the employees are enthusiastic to apply their learning in action. However, the 
quality of training is also very important because it involves the trainees' self-efficacy, as well as the opportunity to do so in relation to a favorable work environment. If the work environment does not support trainees, they will not be interested in applying their knowledge in practice so that performance cannot be improved.

In the present, training programs are understood by organizations not only as an investment that can improve the ability and competence of employees to perform better, but are also understood as a tool that connects the effectiveness of work performance and behavior (Van der Locht et al., 2013). Organizational development also encourages that training must be applicable in the workplace. This means that transferring training positively requires that trainees effectively apply what has been learned to the job, which leads to meaningful changes in performance. Motivation on training transfer is an important element in the training effectiveness criteria, which helps employees and organizations improve performance.

Trainers can also communicate with supervisors about their role in working with subordinates to increase the transfer of training (Bhatti $\&$ Chee, 2012). In practice, supervisors can arrange meetings with trainees, discuss how to apply the skills learned, identify possible support from the organization, provide feedback and recognize when skills learned are transferred to the workplace (Chauhan et al., 2016). Supervisors can also share possible rewards, that is, intrinsic and extrinsic benefits associated with training transfers, which can also motivate employees to transfer skills learned to work. They can cite previous examples of successful employees who transferred their training to work to increase motivation to transfer training (Chauhan et al., 2016). They can assist trainees in formulating and implementing individual action plans for effective transfer of training (Arefin \& Islam, 2019).

\section{CONCLUSION AND RECOMMENDATION}

The results show the significant influence of transformative learning and supervision support on motivation to transfer training. Further- more, motivation to transfer training has a positive effect on improving individual performance. More specifically, supervisor support has an indirect effect on employee performance, through the mediating effect of motivation to transfer learning. Along with the main theory of transformative learning used in this study, this finding affirms that transformative learning is more likely to increase the motivation of private university lecturers to transfer training. This confirms that learning among lecturers to improve capabilities can increase self-awareness to share knowledge and improve institutional performance.

The theoretical implication that the HRM strategy plays an important role in updating lecturer competence through training, because training is seen as an investment to improve performance in response to the strength of the internal and external environment. The managerial implication is that HRM managers need to collaborate with supervisors and trainers on how to support training participants both before and after training. In addition, it must frame training as a program that can motivate lecturers to participate in training programs so that the knowledge and skills learned can be effectively executed with the support of supervisors.

Thinking creativity and employee behavior productivity will develop when presented learning patterns that actualize all employee potential. This implies that transformative learning is able to deliver employees to the learning process that is directed to provide employee independence for critical-creative thinking and innovative productive behavior so as to transform all the potential capabilities they have to improve performance. Theoretically, this finding shows that supervisors have an influence on individual performance in the college work environment. These results theoretically prove that training-based motivation is also adoptable in the college environment. Practically, this finding indicates the need for strengthening supervision in higher education organizations, where supervision chains need to be considered substantially in institutional management. The second practical implication is the need to increase motivation related to training for employees to improve skills, capacity, 
Emiliana Sri Pudjiarti et al./ Motivation to Transfer Training and Individual Performance: the Influence....

and knowledge accompanied by remuneration and bonuses and establishing a conducive work environment.

The limitations of this study only use the cross-sectional method so that they are unable to see changes in the ability of employees from a transformative cleavage model and supervisor support. Future studies are expected to test longitudinally the effect of motivation on individual performance as well as the influence of supervisor support and transformative learning on motivation in tertiary institutions. Further studies are also expected to be able to thoroughly analyze training aspects and priority capacities in improving the performance of tertiary institution employees.

\section{REFERENCES}

Alshery, W. B. R., Ahmad, F. B., \& Al-Swidi, A. K. (2015). The Moderating Effect of Role Ambiguity on the Relationship of Job Satisfaction, Training and Leadership with Employee Performance. International Journal of Business Administration, 6(2), 30-41.

Arefin, M. S., \& Islam, N. (2019). A Study on the Motivation to Transfer Training in the Banking Industry of Bangladesh. South Asian Journal of Human Resources Management, 6(1), 45-72.

Banerjee, P., Gupta, R., \& Bates, R. (2017). Influence of Organizational Learning Culture on Knowledge Worker's Motivation to Transfer Training: Testing Moderating Effects of Learning Transfer Climate. Current Psychology, 36(3), 606-617.

Bates, R., Holton Iii, E. F., \& Hatala, J. P. (2012). A Revised Learning Transfer System Inventory: Factorial Replication and Validation. Human Resource Development International, 15(5), 549-569.

Battor, M., \& Battour, M. (2013). Can Organizational Learning Foster Customer Relationships? Implications for Performance. The Learning Organization, 20(4/5), 279-290.

Bhatti, M. A., \& Chee, H. H. (2012). Resolving the Past Conflict: Role of Peer and Supervisor Support in Training Effectiveness. International Journal of Business and Behavioral Sciences, 2(7), 32-38.

Bjerregaard, K., Haslam, S. A., \& Morton, T. (2016). How Identification Facilitates Effective Learn- ing: the Evaluation of Generic Versus Localized Professionalization Training. International Journal of Training and Development, 20(1), 17-37.

Blume, B. D., Ford, J. K., Baldwin, T. T., \& Huang, J. L. (2010). Transfer of Training: a Meta-Analytic Review. Journal of Management, 36(4), 1065-1105.

Bulut, C., \& Culha, O. (2010). The Effects of Organizational Training on Organizational Commitment. International Journal of Training and Development, 14(4), 309-322.

Campbell, K., \& Vera, A. M. (2010). Female Board Appointments and Firm Valuation: Short and Long-Term Effects. Journal of Management e Governance, 14(1), 37-59.

Chauhan, R., Ghosh, P., Rai, A., \& Shukla, D. (2016). The Impact of Support at the Workplace on Transfer of Training: a Study of an Indian Manufacturing Unit. International Journal of Training and Development, 20(3), 200-213.

Chen, T., Li, F., \& Leung, K. (2016). When does Supervisor Support Encourage Innovative Behavior? Opposite Moderating Effects of General Self-Efficacy and Internal Locus of Control. Personnel Psychology, 69(1), 123158.

Choi, J., \& Jeong, J. (2017). Longitudinal Study on the Relationships among Growth Trajectory Patterns of Investment in HRD, Predictors of Investment in HRD, and Organizational Performance. Journal of Agricultural Education and Human Resource Development, 49(2), 33-62.

Christie, M., Carey, M., Robertson, A., \& Grainger, P. (2015). Putting Transformative Learning Theory into Practice. Australian Journal of Adult Learning, 55(1), 9-24.

Connelly, B. L., Certo, S. T., Ireland, R. D., \& Reutzel, C. R. (2011). Signaling Theory: a Review and Assessment. Journal of Management, 37(1), 39-67.

Dirkx, J. (2012). Nurturing Soul Work: a Jungian Approach to Transformative Learning. A Handbook of Transformative Learning, 116130. San Francisco, Ca: Jossey-Bass.

Dong, Y., Bartol, K. M., Zhang, Z. X., \& Li, C. (2017). Enhancing Employee Creativity via Individual Skill Development and Team Knowledge Sharing: Influences of Dual-Focused Transformational Leadership. Journal of Organizational Behavior, 38(3), 439-458.

Dumas, A., Hanchane, S., \& Silber, J. (2010). On the Link between Investment in On-The-Job 
Training and Earnings Dispersion: the Case of France. In Jobs, Training, and Worker WellBeing, 1-34.

Egan, T. M., Yang, B., \& Bartlett, K. R. (2004). The Effects of Organizational Learning Culture and Job Satisfaction on Motivation to Transfer Learning and Turnover Intention. Human Resource Development Quarterly, 15(3), 279-301.

Ghosh, P., Chauhan, R., \& Rai, A. (2015). Supervisor Support in Transfer of Training: Looking Back at Past Research. Industrial and Commercial Training, 47(4), 201-207.

Govaerts, N., \& Dochy, F. (2014). Disentangling the Role of the Supervisor in Transfer of Training. Educational Research Review, 12(3), 7793.

Hair, J. F. J., Anderson, R. E., Tatham, R. L., \& Black, W. C. (1998). Multivariate Data Analysis, 5Th Edition. Upper Saddle River: Prentice Hall.

Hanaysha, J., \& Tahir, P. R. (2016). Examining the Effects of Employee Empowerment, Teamwork, and Employee Training on Job Satisfaction. Procedia-Social and Behavioral Sciences, 21(9), 272-282.

Hasani, K., \& Sheikhesmaeili, S. (2016). Knowledge Management and Employee Empowerment: a Study of Higher Education Institutions. Kybernetes, 45(2), 337-355.

Heddy, B. C., Sinatra, G. M., Seli, H., Taasoobshirazi, G., \& Mukhopadhyay, A. (2017). Making Learning Meaningful: Facilitating Interest Development and Transfer in at-Risk College Students. Educational Psychology, 37(5), 565-581.

Heilmann, S. G., Bartczak, S. E., Hobbs, S. E., \& Leach, S. E. (2013). Assessing Influences on Perceived Training Transfer: if I only Knew then What I Need to Know Now. Journal of Business and Educational Leadership, 4(1), 3447.

Hersey, P., Blanchard, K. H., \& Johnson, D. E. (1996). Planning and Implementing Change. in Management of Organizational Behavior: Utilizing Human Resources. NJ: Prentice Hall.

Hoggan, C. D. (2016). Transformative Learning as a Metatheory: Definition, Criteria, and Typology. Adult Education Quarterly, 66(1), 57-75.

Holton III, E. F., Bates, R. A., \& Ruona, W. E. (2000). Development of a Generalized Learning Transfer System Inventory. Human Resource Development Quarterly, 11(4), 333-360.

Hossain, A., \& Aktar, N. (2012). Influence of Per- ceived Organizational Support, Supervisory Support, and Working Environment on Employee Service Quality: an Empirical Study on Non-Govt. Employees in Bangladesh, 1(1), 2-24.

Huang, J. L., Ford, J. K., \& Ryan, A. M. (2017). Ignored No More: Within-Person Variability Enables Better Understanding of Training Transfer. Personnel Psychology, 70(3), 557-596.

Huang, J. T., \& Hsieh, H. H. (2015). Supervisors as Good Coaches: Influences of Coaching on Employees' in-Role Behaviors and Proactive Career Behaviors. The International Journal of Human Resource Management, 26(1), 42-58.

Iqbal, K., \& Dastgeer, G. (2017). Impact of SelfEfficacy and Retention on Transfer of Training: the Mediating Role of Motivation to Transfer. Journal of Management Development, 36(10), 1270-1282.

Kirwan, C. (2016). Improving Learning Transfer: a Guide to Getting More Out of What You Put Into Your Training. Routledge.

Liu, X., \& Batt, R. (2010). How Supervisors Influence Performance: a Multilevel Study of Coaching and Group Management in Technology-Mediated Services. Personnel Psychology, 63(2), 265-298.

Martin-Perez, V., \& Martin-Cruz, N. (2015). The Mediating Role of Affective Commitment in the Rewards-Knowledge Transfer Relation. Journal of Knowledge Management, 19(6), 1167-1185.

Massenberg, A. C., Spurk, D., \& Kauffeld, S. (2015). Social Support at the Workplace, Motivation to Transfer and Training Transfer: a Multilevel Indirect Effects Model. International Journal of Training and Development, 19(3), 161-178.

McGonigal, K. (2005). Teaching for Transformation: from Learning Theory to Teaching Strategies. Speaking of Teaching, 14(2), 1-4.

Medina, M. N. (2017). Training Motivation and Satisfaction: the Role of Goal Orientation and Offshoring Perception. Personality and Individual Differences, 105, 287-293.

Mezirow, J. (2000). Learning as Transformation: Critical Perspectives on a Theory in Progress. The Jossey-Bass Higher and Adult Education Series. San Francisco: Jossey-Bass Publishers.

Mezirow, J. (2012). Learning to Think Like an Adult; Core Concepts of Transformation Theory. In Teoksessa Edward Taylor \& Patricia Cranton 
Emiliana Sri Pudjiarti et al./ Motivation to Transfer Training and Individual Performance: the Influence....

(Eds). The Handbook of Transformative Learning: Theory, Research, and Practice. San Francisco: Jossey-Bass Publishers.

Muduli, A., \& Raval, D. (2018). Examining the Role of Work Context, Transfer Design and Transfer Motivation on Training Transfer: Perspective from an Indian Insurance Industry. European Journal of Training and Development, 42(3/4), 266-282.

Namian, M., Albert, A., Zuluaga, C. M., \& Jaselskis, E. J. (2016). Improving Hazard-Recognition Performance and Safety Training Outcomes: Integrating Strategies for Training Transfer. Journal of Construction Engineering and Management, 142(10), 401416.

Nijman, D. J. J., Nijhof, W. J., Wognum, A. A. M., \& Veldkamp, B. P. (2006). Exploring Differential Effects of Supervisor Support on Transfer of Training. Journal of European Industrial Training, 30(7), 529-549.

Njiro, E. (2014). Moving Transfer to Transformative Learning: a Curriculum Model for Adult Educators in Open Distance Learning (ODL). Journal of Educational and Social Research, 4(3), 479488.

Noe, R. A., \& Schmitt, N. (1986). The Influence of Trainee Attitudes on Training Effectiveness: Test of a Model. Personnel Psychology, 39(3), 497-523.

Novak, J. D., \& Gowin, B. D. (2004). Learning How to Learn. London: Cambridge University Press.

Priyotomo, P., Setyowati, R., \& Suharnomo, S. (2019). The Role of Team Building Training on Team Cohesiveness and Organizational Commitment in an International Manufac- turer in Central Java. Quality-Access to Success, 20(172), 40-53.

Reinhold, S., Gegenfurtner, A., \& Lewalter, D. (2018). Social Support and Motivation to Transfer as Predictors of Training Transfer: Testing Full and Partial Mediation Using Meta-Analytic Structural Equation Modelling. International Journal of Training and Development, 22(1), 1-14.

Suparjo., \& Sunarsih, E. S. (2018). The Role of Service Quality and Institutional Image in Establishing Relational Commitment between Private Universities and the Student. Journal of Entrepreneurship Education, 21(3), 1-13.

Tomé, E., \& Goyal, A. (2015). Human Capital, HRD and VET: the Case of India. European Journal of Training and Development, 39(7), 586-609.

Towler, A., Watson, A., \& A. Surface, E. (2014). Signaling the Importance of Training. Journal of Managerial Psychology, 29(7), 829-849.

Tucker, M. K., Jimmieson, N. L., \& Bordia, P. (2018). Supervisor Support as a DoubleEdged Sword: Supervisor Emotion Management Accounts for the Buffering and Reverse-Buffering Effects of Supervisor Support. International Journal of Stress Management, 25(1), 14-28.

Van Der Locht, M., Van Dam, K., \& Chiaburu, D. S. (2013). Getting the Most of Management Training: the Role of Identical Elements for Training Transfer. Personnel Review, 42(4), 422-439.

Wei Tian, A., Cordery, J., \& Gamble, J. (2016). Returning the Favor: Positive Employee Responses to Supervisor and Peer Support for Training Transfer. International Journal of Training and Development, 20(1), 1-16. 